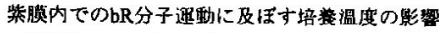

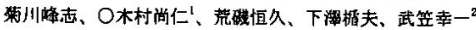

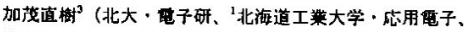

${ }^{2}$ 北大. $工 、{ }^{3}$ 北大·承)

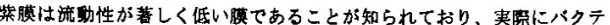

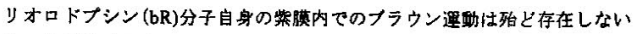

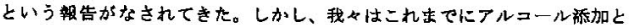
いう外乱を加えた絭膜、あるいはD96N変哄を与えた紫膜内でbR分子は分子

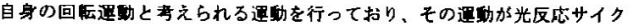
ルに入ると痋くなるという結果を吸収異方性の測定加ら得ている。また、 これらの結果からbR分子閒のinteractionの存在を予想してきた。さらに今回 は、このような外的掫乱を与えずとも、菌の培虽温度を上げることで同㥞 の結果が得られることを見い出したので報告する。

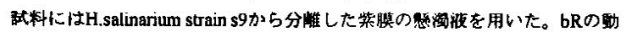

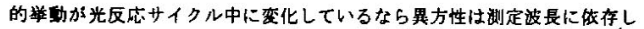

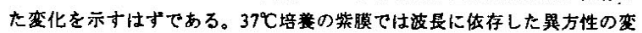

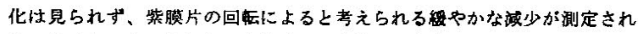
るのみであった。しかし、より高温で培繁した紫膜では波長に依存した非 常に奇妙な穓方性の変化が出現した。この波長哄存の仕方はアルコールを

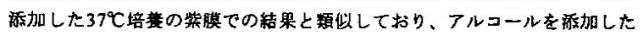

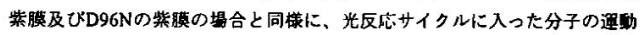
は入らなかった分子に比べ掘くなっていることを示している。また、培費 温度が紫膜の梅造、あるいはbR分子間のinteractionに变化をもたらしている ことは明らかである。

以上の結果は光反心サイクルに入ることで運動が遮くなるという現像か bR分子の本来有している動的性错に由来していることを示㗒している。

なお、吸収偏光解消测定装圈の作成にあたり、御協力頂いた北大・委子 鿬、井上久透教投と山中明生氏に感即いたします。

T.Kikukawa, N.Kimura, T.Araiso, T.Shimozawa, K Mukasa, N.Kamo: Effect of culunire temperature on the molecular motion of bacteriorhodopsin in purple membrane.

\section{F 01}

緑色光合成細菌の反応中心のbacteriochlorophyll -670の機能：。岩城 雅代. 伊藤繁 (基生研) 大岡宏造 . 龟开正一郎 ·松原 央 (阪大.理.生)

•嫌気性緑色光合成細菌(Chlorobium tepidum)の 反応中心(RC)は単一種のポリペプチド鎖2本がコアを 满成する゙ホモダイマー型"で、植物光化学系I RCの原型 と思われる。その内部には30分子のバクテリオクロロ フィル (BChl) a. 反応中心BChl aダイマー (P840) . 46分子のBchl-670(8670:構造はChl a と類(似),及ひ4 $4 \mathrm{Fe}$ 4Sクラスターが存在する.・実験 : urea処理によりR C内のFeSを破壊し.77Kでの閃光分光実験によりクロ ロフィル間の電子移動を調ベた。・結果/考察 : 以下の 機能を持つ3種(@ビーク波長)のB670の存在が示された. 1) P840-FeS間をつなく電子受容体A.@671nm.

2) P 840 近傍に存在して、P840+が作りだす局所電場

に応じてelectrochromic shiftする。@663,678nm。

3) エネルギー移動などに関与する。@667,671nm. 細菌から植物型RCへの進化と(B)ChIの役割を考察する。

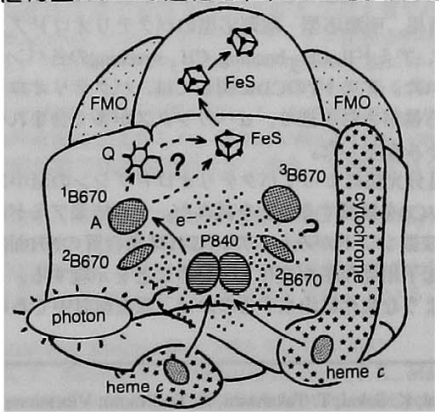

Photosynthetic Reaction Center of Green Sulfur Bacterium, Chlorobium Photosynthetic Reaction
tepidum by M. Iwaki, H. Oh-oka, S. Kamei, H. Matsubara \& S. Itoh

\section{E 24}

D96N変翼bRの筀膜内での分子遇動

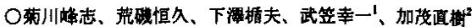

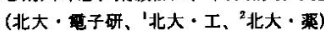

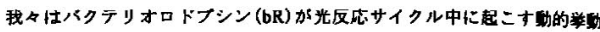
について、これまで竍告されているタンバク笽内部のmicrołconformation changeではなく、レチナールの角度を变化させるようなmacroな举斩の有恶 を吸収鱼方性の測定から检时してきた。これまでの研究により、通营の先

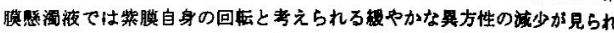
るのみであるが、アルコール秝加によって波曼に在した非常に奇妙な界 方性の変化が出現することを見い出した。この奇妙な異方性の变化仕光反 応サイクルに入っている分子の通偊が入らなかった分子に比へ束編されて いることを示惨している。

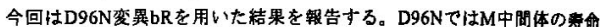

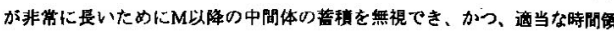
城では光反応サイクルからoriginalに房ってくる分子をも無視できる。従っ て、wild-typeの場合より直接的に光反応サイクルに入っている分子と入らな かった分子の運舫を比較可能である。我々は测定したデータに対し中間体 とoriginalのスペクトルの变なりを考虑した解析を行った。その結果、アル

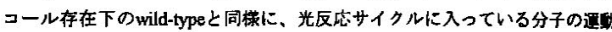

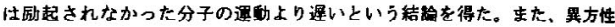
の谈少の仕方から励起されなかった分子の通助は策㬺内におけるbR分子自 身の回忶運動であると考えられる。従って、このような連缜の遥いをもた らす原因としてbR分子間の"interaction"の存在が示惨される。

D96Nの測定はアルコールなしの策件で行っている。よって wild-typeと

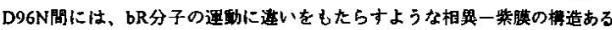
いはbR分子間の"interaction"ーが存在している。

T.Kikukawa, T.Araiso, T.Shimozawa, K.Mukasa, N.Kamo: The motion of D96N mutan bacteriorhodopsin in purple membrane.

\section{$2 F 02$}

械維状緑色細菌と紅色細菌に属す万好熱性菌株の光化学反 応中心タンバク面の分子進化的解析

○花田智、永島堅治、十平石明、嶋田敬三、松浦克美

(都立大·理・生物、ナコニシ㻴境パイオ研)

国内温泉よりバクテリアルマット㥞の密な細菌塊の形成能を持

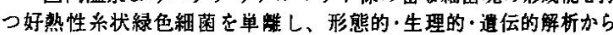
Chloroflexus属の新種たと判断して、Chloroflexus (C.) aggregans 命名した。この新種の光化学反応中心を檕成するタンバク質(ん及 UN sulbunit) をコードする速伝子の塩基配列を決定し、C aurant $i$ acusのものと比較したところ、これらの反応中心遭伝子の相同率は 82. 4\% (L subunit)、87.08 (M subunit)と高い值を示した。 さらら アミノ酸レベルで比較したところ、95.6\% (L subunit)、95.14 (M su bunit)というより高い相同性を示した。この結果とこれら二つの 喠の16SリポソームRNA配列比較から得られた系統的距離とを考えあ わせ、好热性栈維状緑色練菌の光化学反応中心のベブチドの配列变 化には熟的な抑制が鹪いており、それらの保存性が高いことが考え られる。

この考えを梌討するため、新たにバクテリオクロロフィルaを 含んだ好热性の好気性細菌を単龍した。この好熱性新菌株は形態纬 察・色美同定・16SリボソームRNAによる系統解析から縕色光合成耕 菌を含む分類群に属する好気性光合成細菌Erythrobacter、および Porphyrobacterk近䜌のここグルーブでは唯一の好䕀性の新種で あることが分った。現在この新規好熱性細菌の光化学反后中心y ンパクの配列決定を行っており、これら配列の分子進化的鲜析加 ら、光化学反応中心タンバクの進化とその配列変化に対する好熱性 であることの意味について検討する。

S. Hanada, K. Nagashima, A. Hiraishi, K. Shimada, K Matsuura : Moleculler evolusinary analysis of peptides consisted photochemical reaction centers in filamentous green bacteria and purple bacteria. 


\section{$2 F 03$}

杠色光合成倜淢Rhodopseudomonas acidophilaの光捕集色 秦タンバク西LH1の解体とカロテノイドの再模成

○丸山孱、松浦克美、的田敬三

(部立大・理・生物)

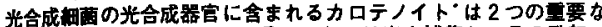

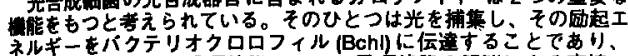

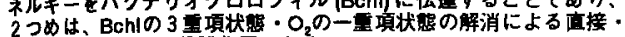

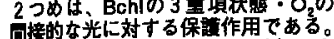

问接的な光に対する保咥作用でする。

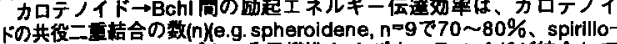
xanthin, $=13$ て30 40\%)、分子律造およびカロテノイドが結合して xanthin,n=ドの浩の造いなとに恢存していると考えられている。

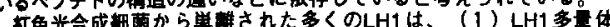

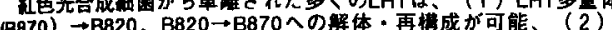
(B870) $\rightarrow$ B820、年を加えて再槽成すると、カロテノイドを含んた B820にカロテノイドを加えて再榑成すると、カ口゙

(2)のような再满成系を用いることにより、1和頑のカロテノイ ドを洁合させた再情成LH1が得られる。この系はLH1タンバク買に

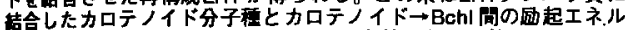

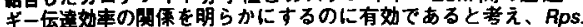

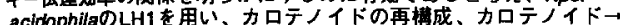

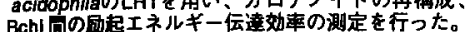

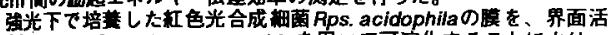
性部n-Octy| $\beta$-D-glucopyranosideを用いて可溶化することにより、

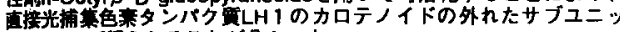
トのB820が得られることが分かった。

このB820にspheroideneを再䊪成した再楧成LH1において的起工

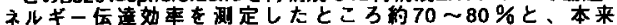
Aps acidophilaOLH1 がもつspirilloxanthin $\rightarrow$ Bchl 间の伝遠効率 (䄪

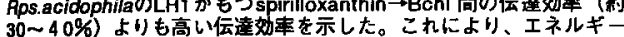
30〜40\%) よりも高い伝達努暒を示した。これにより、エネルギー

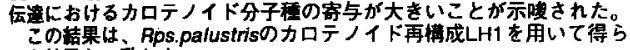
れた拮果と一效した。

さらに、シス型のカロテノイドであるbacteriorubixanthinalの再楼 成LH1ができるこどわかった。こよよう、多租の分子種のカロテ

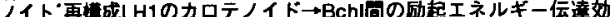
事を㸚定し、エネルギー伝達におけるカロテノイドの寄与を考察した。

S.Maruyama, K.Matuura, K.Shimada :Reconstitution of carotenoids into Light Harvesting complex I from Rhodopseudomonas acidophila

\section{$2 F 05$}

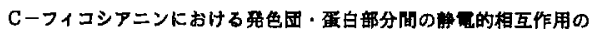
理筑的解析 一 発色団の光吸叹特性に及ぼす影望 菊地浩人"，杉本 微 ${ }^{21}$ ，三室 守"1

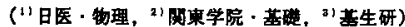

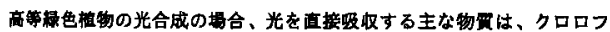
イルである。これは、 $\mathrm{Mg}^{2 *}$ イオンを中心に四つのピロール骤がほほ平面的 に后列したボルフィリン棵と、をの長いフィトールの側鎮とからなってお

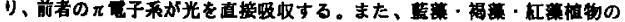

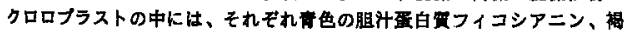
色のカロテノイド色奉フコキサンチン、及び色の䏣汁蛋白買フィコエリ トリンなとがあり、それぞれ裸色の光を吸叹してそのエネルギーをクロロ フィルに吅水に伝建し、光合成の㭪助色来として役たっってい。

本研然では、结晶橉造が分解龍 $1.66 \mathrm{~A}$ で決定されている、Cーフィコ

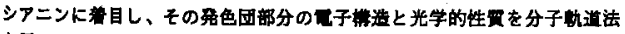
を用いて理的に罱ベることを行う。Cーフィコシアニンは、茟本的に $\alpha$

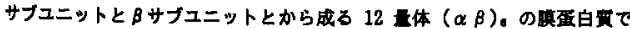

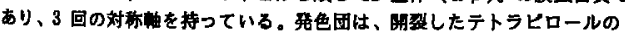
フィコシアノビリンであり、 $\alpha$ サブュニットにーつ、 $\beta$ サブュニットにニ

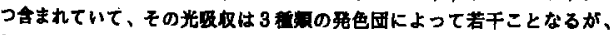
$600 \mathrm{~nm}$ 付近に厔大を持っている。そして、これらの然色団の光吸収はその

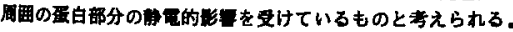

碑方法は、㰠に示すとすりである。まず、ブロティンデータパンクに

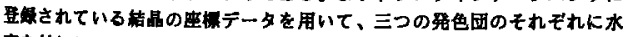
来を付加し、

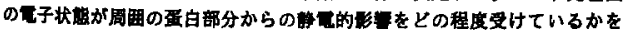

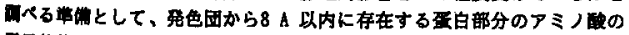

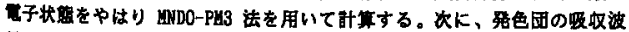
最を计真するために IHDO-CI法を用い、その林算で使用される 2 数のパ

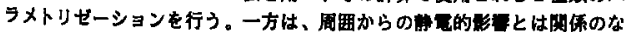

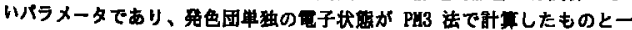

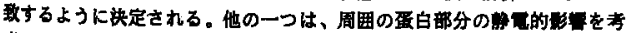

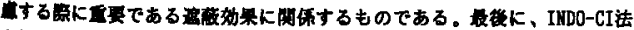
を用いてCーフィコシアニンの光吸帆特性と周围の碰白部分による的

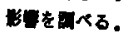

\section{$2 \mathrm{~F}_{0} 4$}

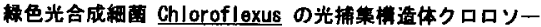

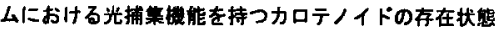
计 公榑、*高市蒖一、忪消克美、O的田敬三

(都立大・理・生物、*日医大・生物)

練色系状光合成細菌 Chloroflexus aurantiacus の光捕集鹪造体 クロロソームは、色素としてはハクテリオクロロフィル(BChI) $\mathbf{c}$ BChl a , カロテノイドを含む。このうち BChl c はクロロソーム内 部("core") で自己会合体を肜成し、Oy逗移モーメントをほほクロロ

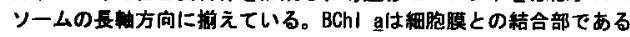
baseplate に存在し、Oy通移モーメントはむしろ BChI c のそれと は直交に近い状㦝にある。カロチノイドについては、“cor日”部分に

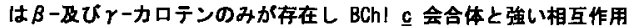
を持つこと、クロロソーム毒底部ではこれらのほかに0H- $r$-カロテ ン眍䊩体の脂肪酸エステルが多く含まれていることをこれまでに明 らかにしてきた。しかし、これらのカロテノイドの存在状怔につい ては未だに不明の点が多い。本年会では“core”部分おけるカ口チ ノイド分子程の特異性およひ配向性について得られた結果について 報告する。

強光下で成育させた菌体から得だcore”部分は弱光下のものより

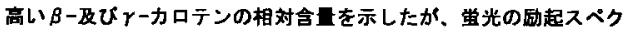
トルから求められた BChI c に励起エネルギーを枟している 及ひrーカロテンの相対量は通常の堨合（䄪 $1 \mathrm{~mol} / 5 \mathrm{~mol} \mathrm{BChl}$ c) と変わ らなかった。すなわち.特暴的な相互作用を行うカロテンの年は

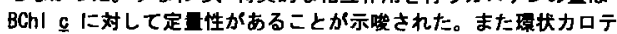
ノイドの合成阻害郕であるニコチンを加えて生育させた荡体から得 たクロロソーム゙core“の监光の䂝起スペクトルからはクロロソーム 中の BChl c 集合体と $\beta$-および $\gamma$ カロロテとの相互作用は分子理 特異性の高いものであることが示惨された。

クロロソームの BChI $\underline{\mathrm{c}}$ 及び a による緟光の傮光解消の励起スぺ クトルの䀧定を行ったところ. BChl c に励起エネルギーを転移して いるB-及ひ $r$-カロテンは BChI $\mathrm{c} の$ Oy遏移モーメントに対して項 いていることが示浐された。

K. Tsuji, S. Takaichi. M. Matsuura, K. Shimada: Specificity and or ientation of carotenoids in chlorosomes of chloroflexus.

$2 F 06$

緑色硫黄光合成細菌 Chlorobium tepidum 光化学反応中心 複合体の電子伝達の分光学的研究

○楠元籍明、井上和仁、富岡厚、桜井英博

(早稲田大·教育・生物、十神奈川大·理·応用生物) 始原的光合成生物である緑色硫黄光合成細菌 Chlorobium tepidum よ り嫌気的条件の維持に細心の注意を払い光化学反応中心䙉合体を精 慗をした。この反応中心複合体は光誘起酸価される反応中心 8840 と 結合型 Cyt $c_{551}$ を持ち、光によって遇元される 3 種の Fe-S センター $\mathrm{CF}_{\mu}, \mathrm{CF}_{\mathrm{B}}, \mathrm{CF}_{\mathrm{x}}$ を結合しており、5ないし6 個のサブユニットで構成さ れていた。連榬光を用いた光化学活性の測定では、複合体に結合して いる全 Cyt $c$ 量の䄪 60\% 加酸化されることから、この標品において湘 定される kineticsが主経路のものであることが示された。そこで mPMS を人工電子受容体としてミリ ms 秒閳光分光により、kinetics およひ差 スペクトルを測定した。測定結果の解析より、差スペクトルの成分は $\mathrm{mPMS}$ 依存成分 (Cyt $c$ 由来)と mPMS 非依存成分とに分けられた。 mPMS 非依存成分のスペクトルは 430 ないし 435nm になだらかな員 のビークを持ち、500nm 付近にまでその裙が広がっでり、PSIにお ける Fe-S センター $\mathrm{F}_{\mathrm{A}}, \mathrm{F}_{\mathrm{B}}$ 由来の P430のスペクトルに類似し、その є 430 は、約 $10 \mathrm{mM}^{-1} \mathrm{~cm}^{-1}$ と見積もられた。これは $\mathrm{P} 430 の \Delta \varepsilon 12$ $\mathrm{mM}^{-1} \mathrm{~cm}^{-1}$ とほほ一致している。これらのことから、 $\mathrm{mPMS}$ 非依存成 分は Fe-S センター ((CFA, $\left.\left.\mathrm{CF}_{\mathrm{B}}\right)\right)$ 由来の光還元差スペクトルであるこ とが示された。ビオローゲンなどの人工電子受容体は䢱元型 Fe-S 七 ンターの舟子受容体となることが期待されるのて、先に得られた mPMS 非依存性吸光成分のスペクトルが $\left(\left(\mathrm{CF}_{\mathrm{A}} \mathrm{CF}_{\mathrm{B}}\right)\right)$ 由来であること を確証づけるために人工西子受容体の mPMS 非依存成分に対するビ

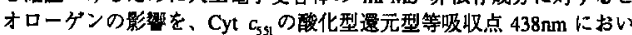
て吸収変化の kinetics を测定した。その結果 benzyl viologen (Em:$360 \mathrm{mV}$ ), methyl viologen (Em:-440mV)では此較的低港度で光誘起吸光 度変化の decay 速度を高めたが、Em:-540mVの triquat は、その効果が 前 2 者よりも低かった。このように人工電子受容体の添加により、 mPMS 非佬存成分の decay が速くなったことからこの decay 成分が Fe-S 由来であるとした我々の結論がさらに善付けられた。

N.Kusumoto, K. Inoue, A. Tomioka, H. Sakurai:

Spectroscopic studies of electron transfur in a reaction center complex from green sulfur bacterium Chlorobium tepidum. 
$2 \mathrm{FO}^{0} 7$

カロテノイドの21Ag電子状想からのフォトルミネッセンス

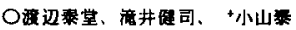

(间学大·理・物理、十间学大・理・化学)

低温汾媒中のカロテノイドにおる省光とその励起スベクトルから、

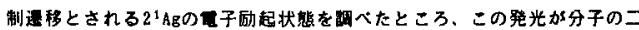

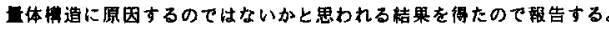

一畎として、150Kにおける TH F 中の全トランスールテイン $\left(1.6 \times 10^{-5}\right.$

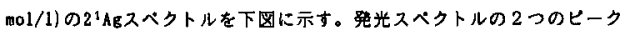

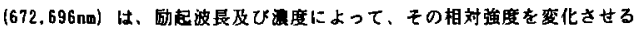

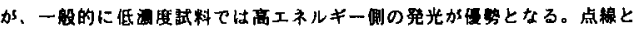

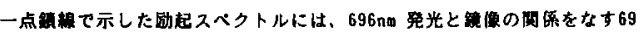

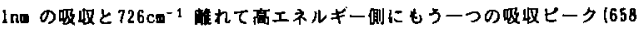

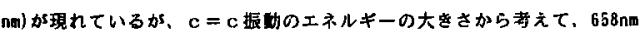
ピークは691 nm 位のhigher levelであることが分かる。この結果は，低

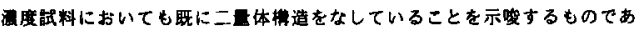
る. $672 \mathrm{~nm}$ 発光の起源については現在のところ明らかではないか、同找の 結果が全トランスースフェロイデンにおいても得られており．码起スベク

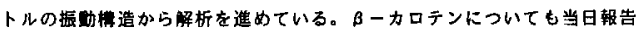
する予定である。

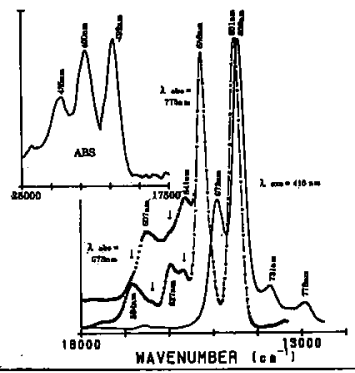

Y. Watanabe. K. Takii. Y. Koyama : Photoluminescence from the $2^{1} \mathrm{Ag}$ electronic states of Carotenoids.

\section{$2 F 09$}

キノン置換PS Iコア複合体の電子移動活性に対する Lタンパク質の効果

○小澤真一郎、豊島喜則（京都大学大学院、人間 . 濖境学研究科)

我々は、高等植物の光合成光化学系 I複合体(PS II)の還 元側 $Q_{A}$ を年する電子移動能に、psbLにコードされたLタン バク質が強く関与していることを再棰成法により明らかに し、既に報告した。このしタンバク質を利用した再構成法を 用いて、タシバク質組成の異なる2種類のPS II コア複合体 (RC)に対してプラストキノン-9(PQ-9)を再構成し、電子移動 活性( $Q_{\mathrm{A}}$ 活性)を測定したところ、Lタンバク質に起因する QA 活性の差が認められた。本研究では、2種のRCに対して ユビキノン $(\mathrm{UQ})$ を再構成した $\mathrm{Q}_{\mathrm{A}}$ キノン置换RCを謂製し、こ れらを用いてレタンバク質の電子移動活性に対する刘果につ いて検討した。

PS I か $5 n$-octyl- $\beta$-D-glucoside/n-octyl- $\beta$-D-thioglu coside 混合可溶化剂処理に上って、CP47/D1/D2/cy tb559/I/(H) のタンバク質組成からなるPS IIコア被合体(RC1) と、 TritonX-100処理によりD 1/D2/cytb 559/Iで棰成されるPS IIコア複合体2(RC2)を調製した。これら2種類のRCに対し てイソブレノイド単位の異なる数種のUQとPQ-9を、キノ ン・digalactosyldiglyceride(DGDG)またはキノン・DGDG · レタンパク質の組み合わせで再構成を行った。その結果、 RC1に対してキノン.DGDGのみを再構成した場合、UQ2,UQ-10,PQ-9で置換したRC1は全て約 $12 \%$ Q $\mathrm{Q}_{\mathrm{A}}$ 活性が認め られた。レタンパク質とともに再構成した場合、QA活性は UQ-2 固換RC1では $23 \%$ 、UQ-10では $32 \%$ 、本来のQAである $\mathrm{PQ} \cdot 9$ では $43 \%$ となり、キノン種によって蛙活性に差が生じ ていた。次に、RC2に対して同粎の再構成を試みたが、 $\mathrm{Q}_{\mathrm{A}}$ 活性はUQ-2,UQ-10,PQ-9を用いたいずれの場合でも約12\% 程度であった。この様に、RC1ではＬタンバク質を加えて 再構成することにより、Q活性にキノンの違いによる差が 現れたが、RC2では多ンバク質による $\mathrm{Q}_{\mathrm{A}}$ 活性回復への効 果は全く認められなかった。以上の結果を基に、電子移動

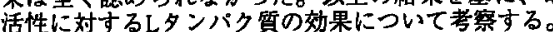

S.Ozawa, Y.Toyoshima: Effect of I protein on the electron transport activity in quinone-substituted PS II core complex.
$2 F 08$

P S II 電子伝達系におけり小サプニットタンバク 質とリン酸化の役割

杉山立志、○星田尚司、豊島喜則（京都大学大学

院、人間 - 環境学研究科)

P S II には機能が未同定の数種の小サプユニットタンバ ク質が存在しており、そのいくつかはP S Iの莩元側での 電子移動に関与している可能性がある。P S II 複合体を混 合可溶化剂で処理し、CP43，H， L， n-5.0，n-4.1，Kタシバク 質、PQ-9、脂貎を可溶化すると、電子移動活性をもたない 反応中心襣合体 (D1/D2/CP47/Cytb559/I：RC)を得る事加 できる。既に報告したように、RCにLタンバク質をPQ-9、 digal actosyldigly cerideと共に再槽成すると約40\%にまで活 性が回復する。一方、RCに可溶化成分すべてを再構成した 時の活性は70\%である。これは完全な電子移動活性の回得 にはLタンパク質以外に可溶化画分に含まれているいづれ かのタンバク質も必要である可能性を示唆している。

RCのSDS-PAGE像からH タンバク質は他の可溶化成分に 比べ可溶化されにくいことがわかった。 RCをさらに混合可 溶化削で処理してHタンバク質を取り除き、この反応中心 複合体に上タンバク質を再構成したときの活性は $25 \%$ で あった。このことからLタンパク質が機能するために忙 タンパク質が必要であると考えられた。これを直接的に調 ベるために、Hタンバク質を単蜼し、Lタンバク質と共に RCに再椿成した。この場合、Lタシパク質単独で再構成し たときよりもさらに高い電子移動活性を示し、この結果加 ら Hタンバク質もPS 【の遇元㑡での電子移動に関与して いることがかかっった。

H、Lタンバク質は光强度に応答してりン酸化を受叮る ことが明らかになっており、光強度に応答した電子移動の 調節に関わっている可能性が高い。これを調べるためリン 酸化、非リン酸化それぞれの H，Lタンパク質を単離し、 これらを用いてRCにQAを再構成した。これらの結果をも とに電子移動に对するリン酸化の役割を考察する。

R.Sugiyama, H.Hoshida, Y.Toyoshima : The regulation of PSII electron transport activity by small proteins and its phosphorylation.

$2 F 10$

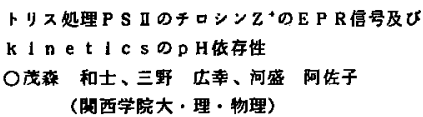

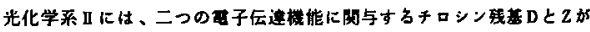

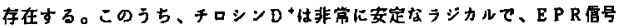
を期測する事が可能である。

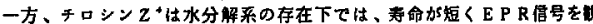
矵する植は困鹳である。しかし、トリス处理により水分解系を除去した式 料では、253 K で光照射後 $77 \mathrm{~K}$ に急凍する本により、チロシン Z+はト ラッブすることができ、E P R 俻号を覞测する事ができる。

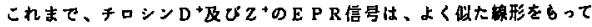
いるとされていた。しかし、我々はрH6．5より低い口H代いて、千

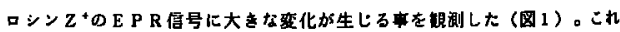

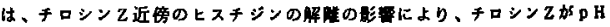
6. 5 付近老境に異なった二つの梅造をとるためだと考えられる。

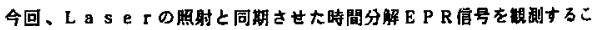

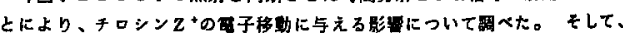

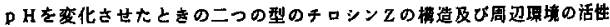
化エネルキーの变化にっいて斑期する。

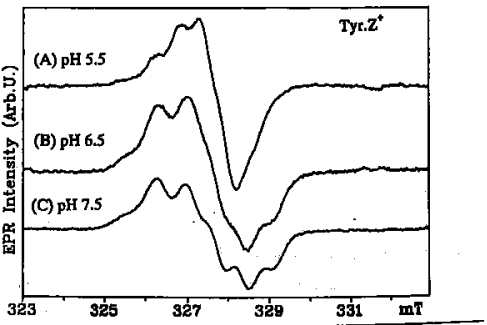

K. Shigemori, H. Mino, A. Kavanori :The pH-dependence of EPR Lineshape and kinetics of Tyr. $Z^{*}$ in Tris-treated Photosystew II 


\section{$2 F 11$}

Parallel Polarizaton EPR による光化学柔II水分解系の視测

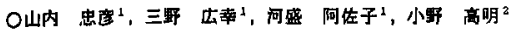

('间西学院大. 理, 2理化学研究所)

光合成光化粪系 II（PＳＩ）内に存在する水分解系は，4個のマンガン

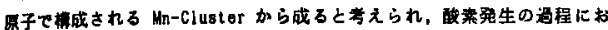

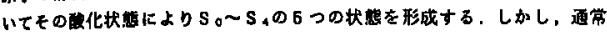

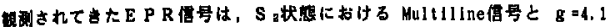

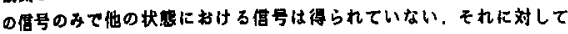

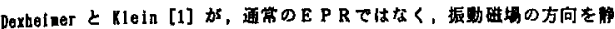

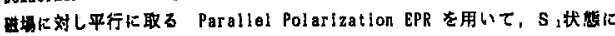

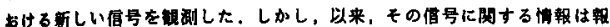
告されていなかった。

我々は，同样に Parallel Polarization EPR を用いる本により，S、信

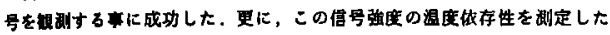
浩果，キニーリーの法则に従わない事が分かった。

また。これとは别に，PS I を医向し Parallel Polarization EPR の角

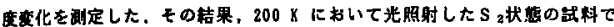

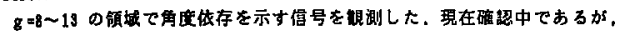

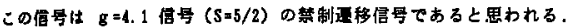
本会では， $\mathrm{s}_{1}$ 信号, $g=8 \sim 19$ 居昂长, yultiline雼甼

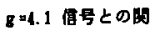

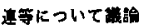
したい.

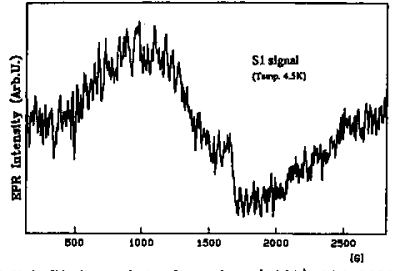

[1] S. L. Dexheiner and M. P.X1ein, J. Am. Chen. Soc. (1992), 114, 2821-28

I. Yanauchi, H. Mi no, A. Kavanori, T. Ono : Parallel Polarization EPR Study of the Photosynthetle Oxygen-Evolving Complex

\section{$2 F 13$}

光合成系ロにおける非へム铁中心のＦＴＩＲスベクトル

○野口 巧、井上賴直 (理化学研究所 - 光合成科学)

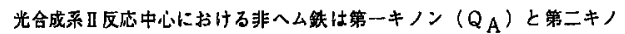
ン $\left(Q_{B}\right)$ の間に位固し、 $Q_{A}$ から $Q_{B} へ$ の电子伝连反応をコントロール していると考えられている。 $\mathrm{HCO}^{3}$ 一非へム鉄への結合がこれに門与 していると言われているが、その結合拣式を含めた非へム鉄中心の構造の 群緗は未だ不明である。本研究では、これらを解明するための第一ステッ ブとして、非へム铁中心のフーリエ変換赤外（FＴＩＲ）スベクトルを測 定した。

光合成系】の非へム筷 $\left(F \mathrm{e}^{2+}\right)$ は、酸化条件下で $\mathrm{F} \mathrm{e}^{3+}$ に酸化さ れ、尝にり再息元されることが知られている。この現象を利用して、フ エリシアン化カリウム存在下で北誘起F T I R 差スペクトル (F e 2+， $\mathrm{Fe}^{3+}$ )を剌定した（下图）。このスペクトルに現かれる主なバンドを フェリノフェロシアン化カリゥム混合液により酸化量元商定すると、 p H

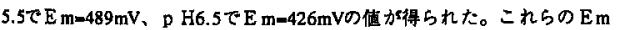
值、及びての嗦存性 $(-60 \mathrm{mV} / \mathrm{pH})$ は、既に知られている光合成系 I の非へム柣の值とはほ一敨してわり、本研究で得られたスベクトルが実际 に非へム鉃中心に由来していることが砤かかられた。

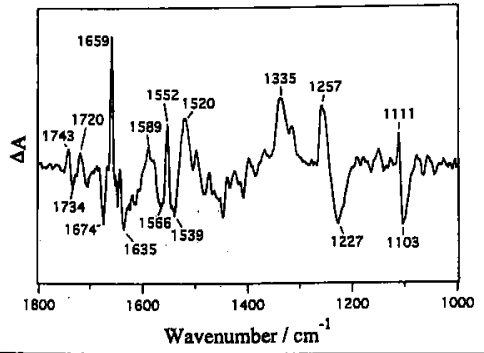

T. Noguchi and Y. Inove: FIIR spectrum of the non-heme iron center in Photosystem II.
2 F 12

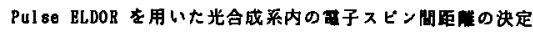

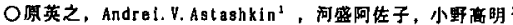
(閶西学院大.理, 1理化学研究所)

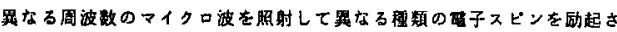

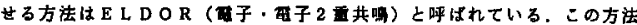

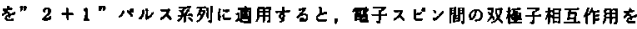

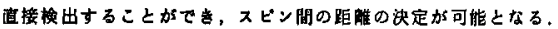

今回は，まず未処理光化学系武料を用いた，この式料では $S_{2}$

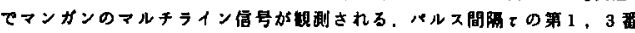
目のパルスでマルチラインのスビンエコーを梲出し，第 2 䊩目のハルスを

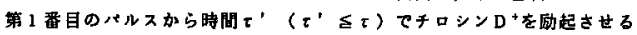
ことによって，チロシンD+のスビンの flip-llop によって生しる、マン

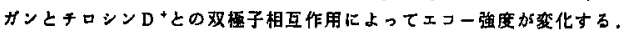

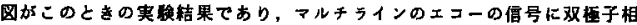
互作用による好果が見られる。このエコー强度は式（1）で示され，

$$
\operatorname{Echo}\left(\tau^{\circ}\right) \propto \cos \left(\frac{\gamma \mu}{\Gamma^{3}}\left(1-3 \cos ^{2} \theta\right) \tau^{\prime}\right)
$$

シュミレーシォンよりチロシンD加らマンガンまでの距䑾を $27 \mathrm{~A}$ と决定

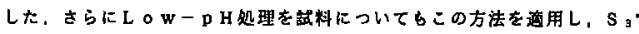
の 2 程頑の信号についていチロシンからの距触の決定を行った．

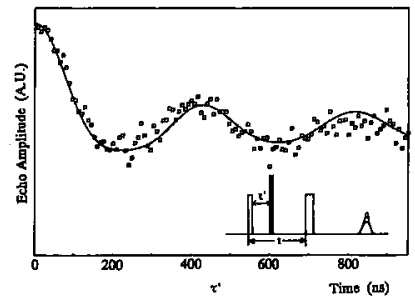

H. Bara, Andrei. V. Astashkin, A.Kawamori, T. Ono H. Hara, Andrei. W. Astashkin, A.Karamori, T. Ono :
Determination of distances between spin species in Photosystea
studied by pulsed ELDOR

\section{F 14}

光化学系 川のKokサイクルにおける最初の水酸化反応中 间体一变形 S3-状態の示す EPR シグナルの理論的解析一 植 正美 (明大理工物理)

植物の光化学系IIの醉化例で起こる水酯化反応、 $\left(2 \mathrm{H}_{2} \mathrm{O}\right)^{*}$ $4 \mathrm{e}^{-} \rightarrow 4 \mathrm{H}^{*}+\mathrm{O}_{2}$, は 4 核 $\mathrm{Mn}$ クラスーを活性中心に、1個の $\mathrm{Ca}^{2+}$ イオ ンと数個のClイオンを補因子とする水分解醉素により触媒され、Kok のS-状態と呼はれる $5 つ$ つ間状態（S0，S1，S2，S3，S4）を程て起こ る。 $\mathrm{Ca}^{2+}$ 除去した光化学系II は、その恣形S2-状態に於いて、 $\mathrm{g}=2.0$ を中心に平均間㟲55-65G で分布した約26本の”率形マルチライン" EPRシクナルを、また変形S3-状億において、g=2.004 中心に 164 G 幅 (Cr-除去、F一阻害、 $\mathrm{NH}_{3}$-処理 及ひ、 $\mathrm{NH}_{2} \mathrm{OH}$ 一処理に依存 して90-240 G幅）の二重項粠造を持つ"S3"EPRシグルルを示す。後者 は、全スピン $S=1 / 2$ のnテトラマーと磁気的に弱く相互作用 $\left(J_{12} S_{1} \cdot S\right.$

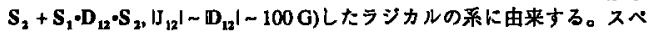
クトルの中心 $(\mathrm{g}=2.004)$ と $\mathrm{Mn}$ テラマーのg-值 $\left(\mathrm{g}_{1}=1.965-2.000\right)$ とか ら、ラジカルのg-值は $\mathrm{g}_{2}=2.010-2.012$ でなければならないと結論され る。この自由两子のbのに比べて高い $\mathrm{g}_{2}$ 一值は、ラジルがスヒンン轨 道相互作用の無視出来ないO-richな分子であることを意味している。 事実、 $\mathrm{His}^{+}+や \mathrm{Y}_{\mathrm{z}}^{+}$・のアミノ酸残基ラジカルの平均g-值はそれぞれ 2.00226と2.0046であるのに対し、OH・PO:・のそれはそれぞれ2.011と 2.015 あることが知られている。更に、"S3"シグナルの理論的解析、 $\mathrm{X}$ 線K吸収端エネルギーのS-状態㑈存性、pH-依存フロトン放出バタ

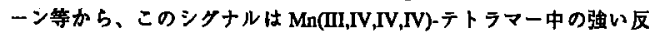
強磁性Mn(III,IV)ダイマーに架栖した (HOOH)・ラシカルによる可能性 が高い。換言すれば、s3-状菂及び变形53-状熊に於いて最初の水の酸 化反応が起こったものと考えられる。また、このシダナルはMnクラ スターの分子楼造に関する情報を含む大変貫重ないのであることを示 す。

M. Kusunoki: The Primary Water-Oxidation-Reaction Intermediate in Kok's Cycle of Photosystem II -Theoretical Analysis of EPR Signals from Modified S3-State- 
绿色光合成細苗クロロソーム中のパクテリオクロロフィルc高次

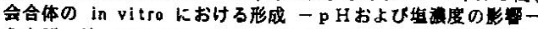

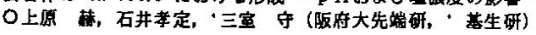

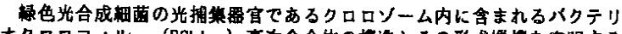

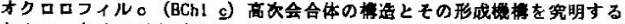

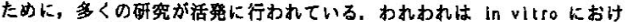

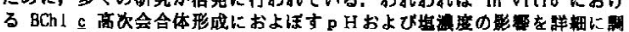
ベたところ興味ある知見を得たので䢁告する。

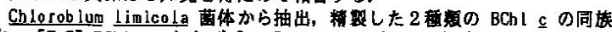
体, $[\mathrm{E}, \mathrm{E}] \mathrm{BChl} \mathrm{gF}$ および $[\mathrm{P}, \mathrm{E}] \mathrm{BCh} \perp \mathrm{cF}$ (Fig. 1) を用いてテトラヒ ドロフラン (THF) -水,アセトンー水, メタールー水およびジメチルス

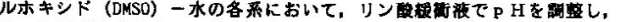

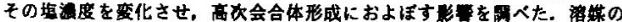

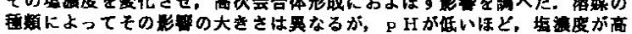
いまど, 得られた $\mathrm{BCh} \mathrm{c}$ 会合体のQyパンドの吸收大がレッドシフトレ

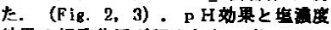

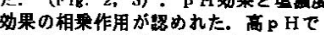
高次会合体の形成が抑制されるのは，

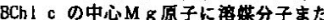

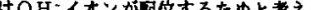
はるH は㙁析妁果に

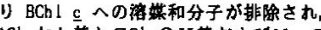
$13^{1}$-ケト基と C3'-OH基および $\mathrm{Mg}$ 聞で, keto $\mathrm{C}=0 \cdots \mathrm{H}-\mathrm{O} \cdots \mathrm{Mg}_{\mathrm{g}}$ 結合による衣

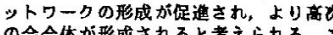
の会合体が形成されると考えられる. こ のことについてCDスペクトルと光敬乱 による数子サイスの揤定から检钨を加える。
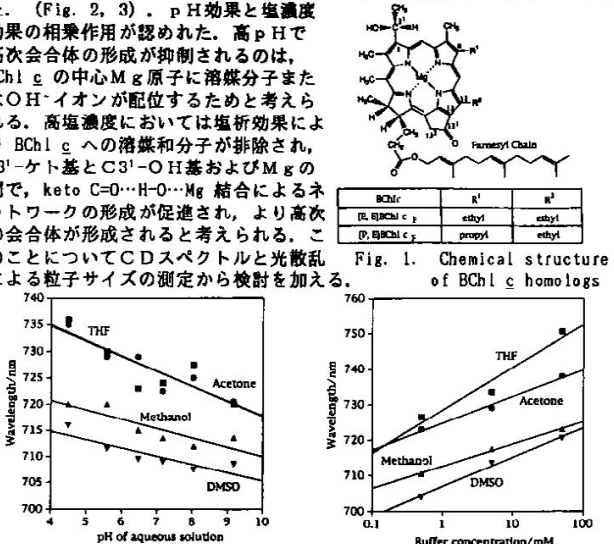
The $\mathrm{pH}$ effect on the aggregation of $[E, E] B C h 1 \mathrm{cr}$ in aqueous solution $(6 x, v / v)$ for $10 \mathrm{mK}$ phosphate buffer

Fig. 3. Buffer concentration effect on the aggregation of [E, E] $B C h I \quad F$ in the aqueous solution for pH 4.49.

\section{F 17}

緑色光合成細菌のクロロソームの長波長型クロロフィル に対するアルコール処理の坛䨌

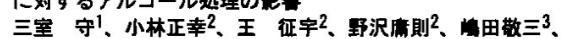

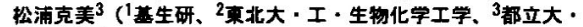
理・生物)

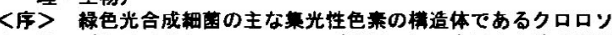
ームでは、パクテリオクロロフィルを(BChI c) の自己会合体が權能

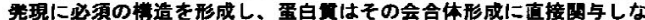

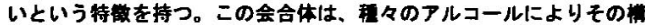

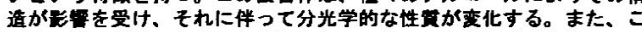
の变化は可逆的でることが知られている。この現象は BChl cにつ いては良く知られていたか、今回新たに、へースプレートに存在する

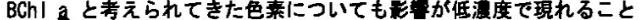
が明らかになったので報告する。

〈方法〉粶色光合成細苗 Chloroflexus aurantiacus t $55^{\circ} \mathrm{C}$ て 培奉し、後期対鹳增殖期の細胞から、Chaotropic anion を用いる方 法でクロロソームを単䧺した。分光学的解析として, 吸収、営光、CD、

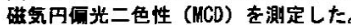

〈結果〉低震度 $(0.3 \%)$ のヘキサノールを加えると、790 nn の

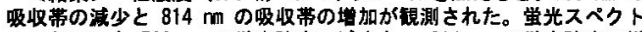
ルにおいても $799 \mathrm{~nm}$ の営光强度の減少と，814 $\mathrm{nm}$ の虽光強度の地

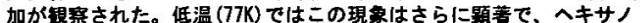

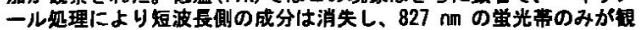

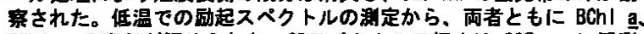

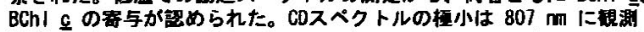
され、へキサノール処理によってはほとんどその強度は変化しなかっ た。一方、MCD スペクトルの枉大は $792 \mathrm{~mm}$ に位皿し、その抯度はへ キサノール処理により約 $1 / 2$ に汥少した。

ヘキサノールは直接 BChI \& に配位することにより会合体の解麇を

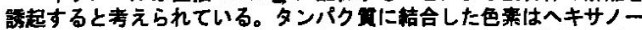
ルに対する感受性が低いと考えられることから、792 nm 成分は BChi c の畏波長タイプの会合体の可能性が寺えられる。しかしその励起ス ペクトルには低温においても BChI a 分子からの等与が BChI cから の旲与と同程度にあり、BCh! aと共通のエネルギーのプールを㩐成 すると考えられる。

M. Mimuro, M. Kobayashi, Z. $-Y$. Wang, T. Nozawa, K. Shimada and K. Matsuura; Effect of alcohol treatment on a long wavelength chlorophyll form of chlorosomes isolated from green photosynthetic bacteria.
ショウジョウバエ視細胞における視物兵帢送と位号 衮換系の関連

○尾崎浩一、十蟻川兴太郎、片野坂公明、河野明子、 徳永史生 (大阪大 ·理、十横浜市大·生物)

ショウジョウバエ視細胞を青色光で照射すると、光信号 変換系が活性化され、PDAを発生する。この青色光照射後 の視物犋合成過程を調べたところ、分子量35k (SDS-PAGE) の成熟オプシンは合成されず、それよりもやや大きい、37 kオプシンの蓄積が観察された。このオプシンをPNGaseFで 処理すると、みかけの分子量は37kから35kに城少するのに 対し、EndoHではこの減少が見られないことから、37kオプ シンは、プロセシングを受けた糖鎖を結合する未成熟オプ シンであることがわかった。同様に青色光照射した八エの

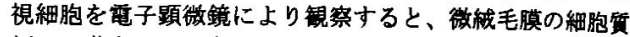
側への落ち込みに加え、SRCの消失と多量の粗面小胞体の 微絨毛直下での集積が観察された。微䋐毛膜の落ち込みは 青色光照射直後に起こるのに対し、粗面小胞体の集㮴には、 オブシン合成の時間経過と対応して、数〜10時間程度を要 した。以上の結果から、青色光照射により蛋白質の小胞体 から微絨毛膜への輸送がブロックされ、成熟オブシンの合 成が阻害されることが明らかになった。更に、光信号変換 系の酵素であるPLCを欠く突然変異体 (norpA) では、青色光 照射後も正常なオプシンの合成が起こること、DG kinase の変異体 $(r d g A)$ では、青色光刺激なしでも未成熟オプシン が蓄樌することなどから、信号変换系の活性化によるPI代 勆の変動が、視物質の合成・輸送と密接に関係しているこ とが示唆された。

K. Ozaki, K. Arikawa, K. Katanosaka, A. Kohno, F. Tokuna ga: Signal transduction and rhodopsin transport in Drosophila photoreceptor cells.

\section{$2 F 18$}

大腸菌アミノ酸感覚レセプターによる

リガンド識別に関わろ領域の同定

O服部文幸、川岸郎朗、本間道夫 (名大·理・分子生物)

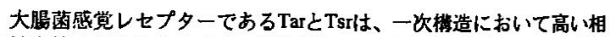
同性を持つにもかかわらず、それぞれアスパラギン酸とセリンを特翼 的に認識し分ける。これまで変異レセプターの解析により、リガンド 認識に重要な残基としてArg64, Arg69, Arg73, Thr154 (Tsrでは Thr156) が同定されているが、これらは両レヤプターで完全に保存されてお り、2つのレセプターの㒛識特異性がどのようなメカニスムに基つく のかは大変興味潹い問題である。最近MilbumらによりTarリガンド結 合ドメインの 3 次元結晶解析がなされた。その結果によると、リガン ドと直接相互作用する残基のうち、Tsrで保存されていない残基は Tyr149（TsrではPhe151）のみである。我々は、この残基か認識特異 性を決定しているのではないかと考え、TarのTyr149 よTsrのPhe151 をそれぞれPheとTyrで置換した変異レセプターを作成し、その性質を 調ぺた。しかし、いずれの変異レセプターのリガンド識別能も野生型 と比較して大きな変化はなかった。この結果から、リガンド証煐特異 性は単に 1 残基の違いでは説明できないことが示された。

そこで我々は、レセプターのどの部分がリガンド識別に重要かを同 定することを試みた。李ら (1989年度年会) はすでにつのキメラレ セプターTasr-SacとTsar-Sac (図参照) を作成し解析している。今回、 他のリガンドに対する応答も含めて詳細に解析したところ、訊暭特異 性がやや䁔眜になっていたが、紷して切り替え部位のN末端側でリガ ンドを㒛識する事が確認された。さらに、新たなキメラTasr-Pst と Tsar-Pst (図参照) を作成し、解析した。この場合は、切り替え部位 よりC末端侧のレセブターと同じリガンド特異性を示した。これらの 結果から、TarとTsrのリガンド認識特哄性は、主に61-88番目の我基間 で決定されることが明らかとなった。今後さらにリガンド識別に必須 な領城を絞り込む予定である。

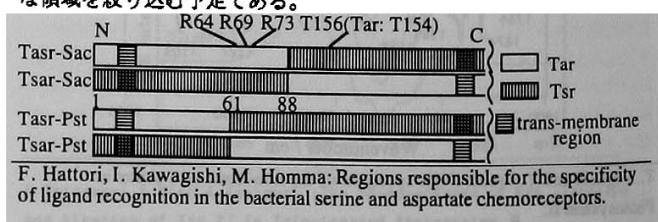




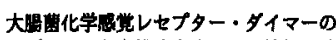

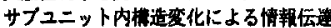

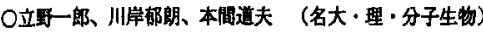

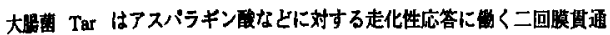

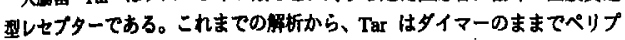

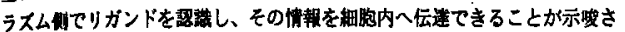

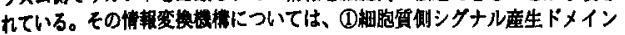
のサフコニット「間」相互作用または(2)サブュニット「内」楼造变化を重要

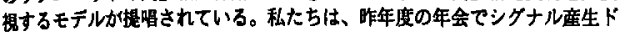
メインのほとんどを欠失した Tar-A198E を Tar-A19K と共存させると、 サプユニット間で抑代がこることを報告した。この結果は、Tar ダイマー

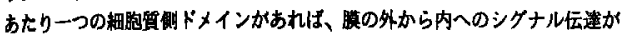

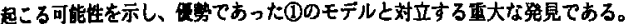
本研究ては、さらに、和购留揤ドメインをどこまで久失可能なのかを解析す

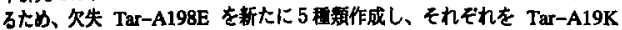
と同時に発现させて解析した。をの結果、シタナル産生ドメインの全てとリ

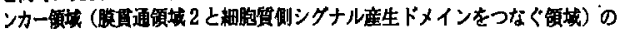
75\% まてを欠失させても、野生型に近い走化性応答を示した。次に、レセ

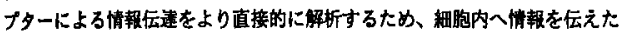
昸の西底に伴う、レセブタータンパク算のメチル化について調べた。るの結 果、これまてに作製した全へテロダイマーは、アスパラギン酸やグリセロー

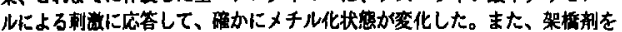
用いてヘテロタイマー形成を直接示哕するような結果を得た。以上の結果は、 (2のモデルを支持するすのである。

上道の欠失 Tar-A198E 加さらに3アミ/酸を欠失させたものは、Tar一 $\mathrm{A} 19 \mathrm{~K}$ と同侍に発现させたとき、菌の走化性庶答能加大きく低下した。した

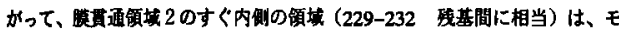

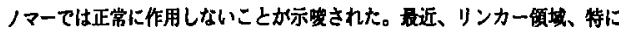
231 番目のアラニン浅基が Tar の情㫰伝撻に重要な役㕮を果たしている可 施性加指捕されている。この棕域におけるサプユニット間の相互作用办蹎の 外加内へのシダナル伝䞗に一定の役割を果たしているのかもしれない。

L. Tatsuno, I. Kawagishi, M. Homma: Transmembrane signaling via intrasubunit structural change in the bacterial chemoreceptor homodimer.

\section{$2 F 21$}

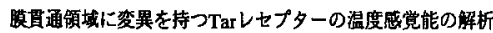
○西山宗一郎、川岸都朗、“丸山一郎、本間道夫 （名大・理、・米国・スクリプス研究所）

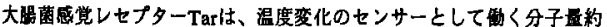
60kDaの腈貫通型タンパク算であり、特定の化学物質や $\mathrm{pH}$ 変化す検知でき

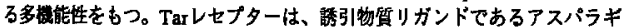

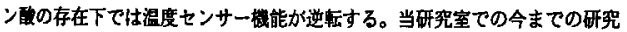
於、この逆轻には、アスパラギン酸への道底の際に生しる細胞質内領域の メチル化の傕行加主に関与していることが明らかになっている。しかし細胞 内フラタメントTarだけでは温度センサー阵能を示さない（昨年の年会て報 告济) のて、他の领域も必要であると思われる。一方、化学刺滰の受容・伝

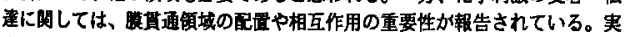

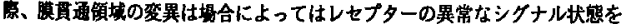

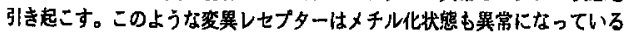
ことが多く、通常とは異なった温度センサー椎能を示す可能性がる。

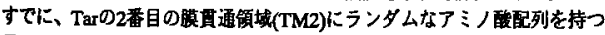
変異Tarか作製され、それらの中で化学受容能を保持している変異Tarのア 磁列の比较から、そこに一定の法則があるとが見出されている(九山 ら、未発表)。今回はこれらの変異Tarの温度センサ一阵能を解析した。

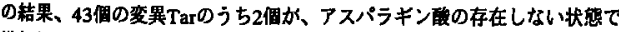
逆年した温度センサー楼能を示すことが明らかになった。これらの変異Ta 生化学受容能を保持しているので、温度受容にのみ特異的な举動を示寸昔重 な変異体でる。この発見によって、アスパラギン酸の存在自体は温度受容

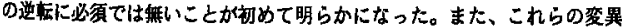

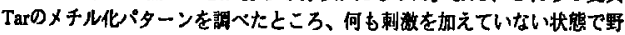
生型Tar占りメチル化が進行していた。従って、このリガンド非传存性の道 云温度受容估、答異によってメチル化が通常より進行している可能性が考元 られる。その一方て、この现象がTM2領域の装によって直接引き起こさ れていて、メチル化の進行は笚に変異によるシグナル状然の異常をを反映し ているに遇きない可能性もあるのて、、今後これらの変異Tarをメチル化醭素 久相株中て発現させ温度受容能を解析する予定でちる。

S. Nishiyama, I. Kawagishil. Maruyama, and M. Homma. Thermosensing properties of bacterial thermosensor Tar mutants with altered transmembrane segments.
2 F 20

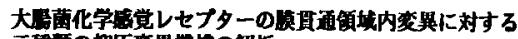

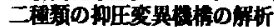

○上田哲司 $1 、$ 川岸郁期 1 、大澤研二 ${ }^{2}$ 、本間道夫 1

('名大·理·分子生物、名大大学院·多元数理)

大腾菌細胞膜に局在するアスパラギン酸感覚レセプターTar は、ペ

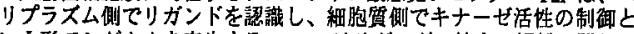
いう形でシグナルを库生する。Tar はリガンドの結合・解郶に関わら ず木モダイマーを形成している。つまり、タイマー内に生しる粠造紊 化によって膜の外加ら内人の情報伝達加起こる。二の際、膜鿓通領域 どうしの相互作用か重要と考えられるか、その实態は不明である。

Tarの二つの膜鿓通領域（TM1，TM2）のうち、TM1 に贸異(A19K) か珄じると、アスパラギン酸結合能は正常だか、情報伝達能を失う。こ の A19K 変異から、多数の遗伝子内挪压変異吕単離されているが、を のほとんどが TM2 またはリンカー領域（TM2 とシダナル産生ドメイン をつなく領域)に存在していた(1)。をこで本研究ては、A19K 変異と

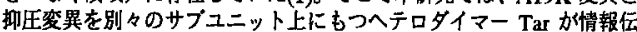
迬可能かどうか解析した。その結果、TM2 内の抑圧変異は、サブュニッ 卜「間」て A19K変異を抑压した。これは一つのサプニットの TM1 と別のサプュニットの TM2 が相互作用することを示惨している。しか

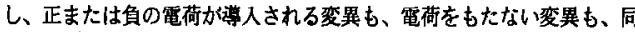
梾にサフュニット間排压を示したことから、これらの残基と TM1 内の A19K办值接相互作用する可能性は低い。一方、リンカー颃域内の抑圧 変異では、サブユニット「間」挪压は起こらなかった。すてに我々は、 シグナル伝達に估、細胞質侧でのサブュニット「間」相互作用は必要 ないことを示哕する結果を得ている(2)。したがって、細胞外の情報は、 膜貫通領域とリンカー領域のサプュニット「内」相互作用によって、 それぞれのシグナル産生ドメインへと后えられるのてはないかと考え られる。現在、これら二㮔類の抑代機構について、部位特異的変買法 やランタム変翼学入法を用いて、さらに解析を進めている。

1. K. Oosawa and M. I. Simon. (1986) Proc. Natl. Acad. Sci. USA 83: 6930-6934.

2. 立里一郎、川岸郁朗、大潔研二、本間道夫 (1994) 生物物理 34: S104.

T. Ueda, I. Kawagishi, K. Oosawa, M. Homma: Analysis of two distinct types of suppressors for a mutation in the transmembrane segment of the bacterial chemoreceptor.

\section{$2 F 22$}

大渴酎化学感觉レセブターのメチル化によるフィードバックが

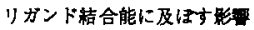
○岩間智德

('岐导大·教表、"名古屋大·理·分子生物)

大渴菌はアミノ酸や糖などを、膜雷通型蛋白啠である化学感営レセブタ ーによって感党受容し、走化性応答を示す。このとき、誘引物縝の涯度そ のものではなく、湛度の時間的変化か留知されている。このためには、ー

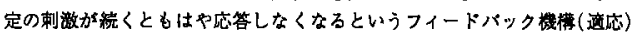
が必須である。暗応には、レセフタター細胞筫㑡ドメインの可逆的なメチル

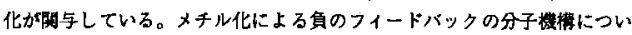
ては、(1)レセブターの誘引物質に対する親和性が低下する、または(2)親和 性は変化せずシグナル産生能か䃪化するという二つのモデルが提唱されて いる。本研究では、この点について、セりン感觉レセブターTsr の部位特 異的化学修㧱法を用いて検討した。

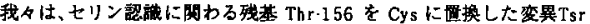
(Tsr-T 156C) が、N.エチルマレイミド (NEM)によって強く修㶦きれ、七 リンの存在下で作既量加诚少することをすで報告している(1)。この リンによる保绫効果がレセブターのセリンに対する親和性を反映している ことを利用し、レセブターのメチル化とリガンド秙合能の䦕係を in vitro

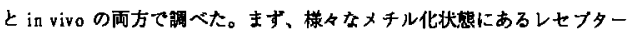

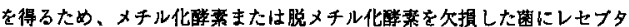

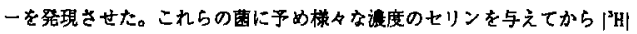

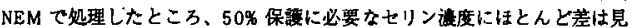
られなかった。次に、それぞれの闌から膜画分を調製し、オクチルダルコ シドを加えてレセブターを抽出した。この践料を、in vivoと同楝に処理 したところ、50\% 保落に必要なセリン漠度は、レセブターのメチル化状 热に関わらずほほ一定であった。これらの結果梳、レセブターのリガンド に対する親和性がメチル化によって変化しないことを示し、(2)のモデルを 支持するいのである。

(1) Iwama et al. (1995) J. Bacteriol, 177: 2218-2221 T. Iwama, I. Kawagishi, M. Homma : Effect of negative feedback via methyl ation on ligand-binding ability of the Escherichia coli serine chemor eceptor. 
2 F 23

ソウリムシの光と温度基觉受容系の共通性

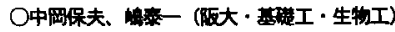

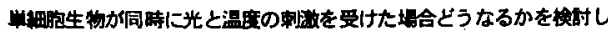
た

これまでに我々はソウリムム (Paramecium) の光とか温度感笕の要

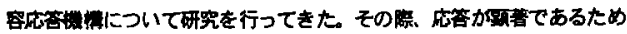
に光感觉は中.bursariaを用い、温度感賞はP. mu timicronucleatumを用 いて实碳を行った。

最近、この相み合わせを变えるとどうなるかを見たところ、P、

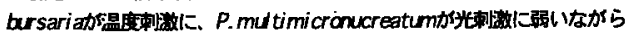

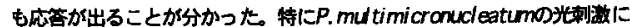

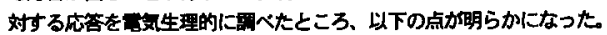

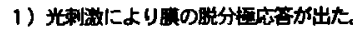

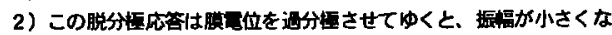

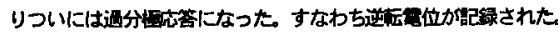

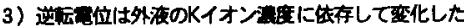
$\left(45 \mathrm{mV} / \log \left[K^{+}\right] 0\right)$

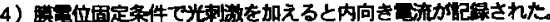

5）内向き流発生時の腊コンダクタンスは減少していた。

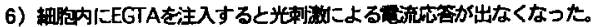

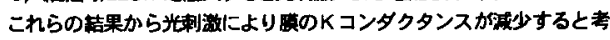
えられる.

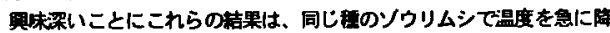

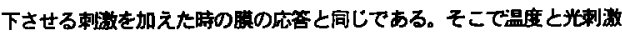
の受谷応管采には共通する部分がちると予想されるので、さらに睡しい 䱊を行い蛣果を報告する。

Y. Nakacka, T. Shima: Common parts between photo and thermo-sensory systems in Paramecium.

\section{$2 \mathrm{G} 02$}

筋小胞体カルシウムAT Paseチューブ状結晶 の電子缐三次元構造解析

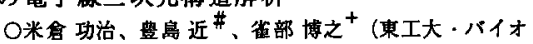

サイエンス、\#東大·分生研、理研・フロンティア)

氷包埋蚳温電子㩆敞鏡法で、筋小胞体カルシウムATPaseのチ エーブ状結晶から、三次元㛵造の解析を行っている。 昨年の年会では分解能を上げる種々の武みについて埌告しだ。 それらの方法を用いて、11本のチューブを平均化した結果、 ATPの加水分解されないアナログであるクロミウムATPを結合し たカルシウムATPaseの構造を9A分解能で解析することができた。 これにより、朝内を貫通する $\alpha$ らせん数本が解像できた。

すでに、ATP非存在下の榑造の 14 A分解能での解析から、䐜 内はA(A1,A2),B,C という3 つのセグメントからなるということ がわかっていだ、分解能が向上した結果、A1，A2が少なくとも 4つのaらせんから暳成されていて、中央に究か存在することが わかった。イオンの通り道はA1，A2の㜔界にあると予想されてい たが2、この穴がそれに対応するのかもしれない。また、Bは2本、 Cは1 2本の $\alpha$ らせん加ら棬成されているようである。

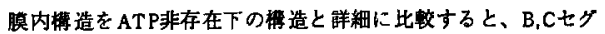
メント等の配雷が異なっていた。これは、ATPの結合によって、 蕆内セダメントが棰造変化したためと考えられる。そこで、ATP 非存在下の構造をより高分眾能で解き、ATPの結合に伴う棬造变 化を二次撞造レべルで、解像することを目指している。 1) 米會 $5:$ 日本生物物理学会第 32 会年回諈演（1994年9月） 2) Toyoshima, C et al:: Nature 362,469-471(1993)

K. Yonekura, C. Toyoshima and $H$. Sas abe Three-dimensional Structural Analysis of $\mathrm{Ca}^{2+}$ AT Pase from Sarcop lasmic Reticulum
2 G 01

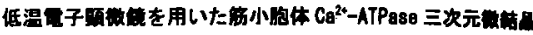
の模造筆析

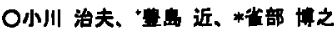

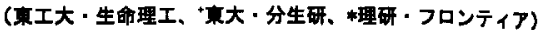

筋小胞体 $\mathrm{Ca}^{2+-A T P a s e}$ は ATP 1 分子の消费比察し、2 個の $\mathrm{Ca}^{2+t}$

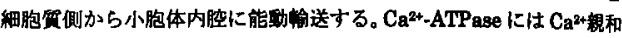
性の高い $\mathrm{E}_{1}$ 状椎と、親和性の低い $\mathrm{E}_{2}$ 状態とがある。

$\mathrm{Ca}^{2+-A T P a s e}$ を可客化、精製の後、リン脂留で再楼成し、界面佸性 刘を高 $\mathrm{K}^{+}, \mathrm{Ca}^{2}+$ 存在下で透析すると、ジーが稓み重なった形状をし た大きさ数 $\mu \mathrm{m}$ の三元微結晶ができるり。これは $\mathrm{E}_{1}$ に相当すると

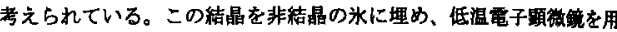
い写真を振影した。三次元結昆であるので橡々な方向の写真が得られ たが、特に(0,1,0)面に垂直な向きから見たと思われるものを造ひ面儌 解析を行った。この棬造と既に 15 A分解能で解加れている $\mathrm{E}_{2}$ 状僬の

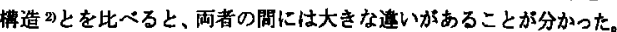
この三次元微結晶は ATPase 活性を示さなかった。また活性湖定と

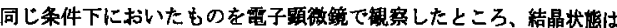
俠然保たれていた。界面活性剂を用い結晶を可溶化したものは活性を 保持していたので、本結晶は何らかの槽造的制約のため活性を示さか いと考えられる。だか、結昆に ATP を加えて一定時間後、無機リン 酸の定量を行ってみると、蛋白量とほほ同量のリン酸が検出されたの で、現在結晶に ATP を加えたものが醉柰反応サイクル中のどの過程 に相当するかを同定しようとしている。

1) Stokes,D. et al. : Biophis.J. 57, 1-14(1990)

2) Toyoshima, C. et al. : Nature 362, 469-471(1993)

H. Ogawa, C. Toyoshima, and H. Sasabe Structural study of 3D micro crystal of $\mathrm{Ca}^{2+-A T P a s e}$ using frozen. hydrated electron microscopy.

\section{G 03}

バクテリオロドブシンのプロトン怡送速传に対する $\Delta \mathrm{pH} \Delta \Delta \Psi$ の剂果

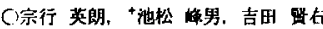

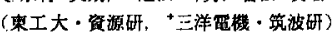

イオンポンプは生体㬴において化学反店や光反応のエネルキーをイオンの

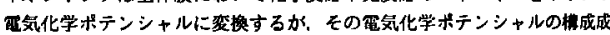

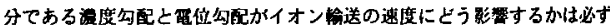
しも明らかてはなかった。昨年の本年会において我っは，人亡平面膜に再

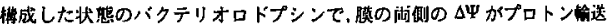

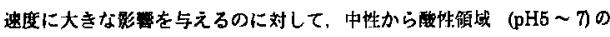

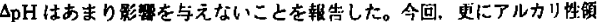

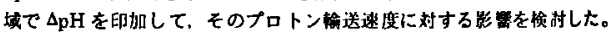
その結果、アルカリ性領域 $(\mathrm{pH} 7 \sim 9)$ でちプロトン䇶送速度估 $\Delta \mathrm{pH}$ の影

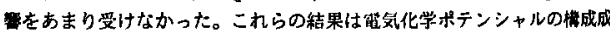

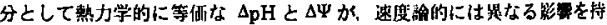
つことを明らかに示している。そして、バクテリオロドプシンにおいて゚ ロトン取り込みに関する部位はプロトンに対する親和性が非常に高く。

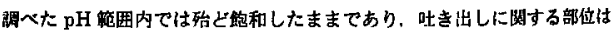
ブロトンに対する親和性が非常に低く、調べた箱围内では殆ど解部したま まであること、全体の律速段階が強い娟位偖存性を持つ非倠定されるか

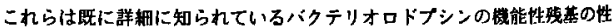
啠と良く一致するちのである。つまりプロトン取り込みに必須てちる Asp96 は基底状盟において pKa が11 以上と推定されて括り，二の牫基 は実験条件下では常にプロトン化している。またプロトン性き出し莭の必 須残基でる Asp85の pKa は 2 程度と推定されており，やはり実确条件

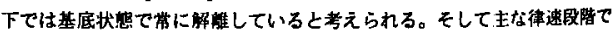
ある $\mathrm{M}$ 中間体の前壊は Asp96 からシッフ塩基へのナ゚ロトンの移种を伴う

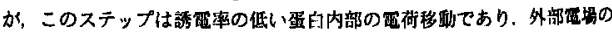

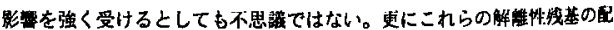
列順序などのプロトンポンプ機能に対する意味などについて考察する。

E. Muneyuki, M. Ikematsu, M. Yoshida ; Effect of $\Delta p H$ and $\Delta \Psi$ on the proton translocation catalyzed by bacteriorhodopsin reconstituted into planar bilayer membranes 